\title{
VULNERABILITIES OF INTERNAL RETURNEE MIGRANTS IN THE CONTEXT OF THE COVID-19 PANDEMIC IN INDIA
}

\author{
Arun Kumar ACHARYA', Sanjib PATEL"
}

COBISS 1.01

\section{ABSTRACT \\ Vulnerabilities of Internal Returnee Migrants in the Context of the COVID-19 Pandemic in India}

The study surveyed 227 returned labor migrants in four districts of western Odisha to comprehensively analyze the socio-economic vulnerabilities faced by internal returnee labor migrants caused by the COVID-19 pandemic in India. The results show that the partial and complete lockdown caused factory and workplace closures in the entire country. Consequently, millions of migrants suffered a loss of income and faced an uncertain future which motivated migrant workers to return to their home villages. Upon arrival, they met socio-economic vulnerabilities, encountered social and economic discrimination, and were excluded by their family members and fellow villagers, which impacted their behavioral health.

KEYWORDS: internal returnee labor migrants, COVID-19, vulnerabilities, India

\section{IZVLEČEK}

Ranljivost notranjih migrantov povratnikov med pandemijo Covida-19 v Indiji Študija zajema 227 notranjih migrantov povratnikov s štirih območij zahodne Orise in prinaša temeljito analizo socialnoekonomske ranljivosti, ki so ji bili zaradi pandemije Covida-19 v Indiji izpostavljeni notranji migranti povratniki. Rezultati kažejo, da sta delni in popolni lockdown povzročila zaprtje tovarn in delovnih mest po vsej državi. Milijoni migrantov so zato izgubili dohodek in se soočili z negotovo prihodnostjo, kar jih prisililo k vračanju v domače vasi, kjer pa so naleteli na vse oblike socialnoekonomske ranljivosti, družbeno in ekonomsko neenakopravnost, iz skupnosti pa so jih izključili tudi družinski člani in sovaščani. Vse našteto je negativno zaznamovalo njihovo duševno zdravje.

KLJUČNE BESEDE: notranji delovni migrant povratnik, Covid-19, ranljivosti, Indija

$\mathrm{PhD}$ in anthropology, UNAM, Mexico; professor, Department of Anthropology, Sambalpur University, Odisha, India; acharya.iinso@suniv.ac.in, https://orcid.org/0000-0002-2696-3038.

\| M.Phil in anthropology, Sambalpur University, India; research scholar, Centre of Excellence: Regional Development and Tribal Studies, Sambalpur University, Odisha, India; sanjibpatel356@ gmail.com, https://orcid.org/0000-0003-2476-1069. 


\section{INTRODUCTION}

Since the first cases of COVID-19 were confirmed in December 2019, to date, just over 108 million people have been infected worldwide by the new SARS-CoV-2, and around 2.3 million have lost their lives (WHO 2021). Governments of all countries have implemented different measures since the beginning of the pandemic. One of the strongest measures has been the need for physical isolation and distancing, suspension of non-essential activities - all intending to curb the spread of the virus among inhabitants and its spread in their territories (Rajan et al. 2020, de Haan, 2020).

India reported its first case of COVID-19 on January 30, 2020 (Government of India 2021). As of April 4, 2021, India has the largest number of confirmed cases $(12,485,509)$ in South-East Asia and the second-highest number of cases worldwide after the United States (WHO 2021). Among the pandemic's innumerable impacts, it has widely affected the migrant population due to the total closure of economic activities (Rajan et al. 2020).

The country-wide complete lockdown during March and April 2020, followed by the imposition of partial lockdown in many states, caused an exodus of migrants workers. As factories and workplaces closed down, millions of migrant workers had to deal with the loss of income, loss of jobs, food shortages, and an uncertain future (Kakar 2020; Pandey 2020). Some media reported that millions of migrants have returned to their home states (The Hindu 2020a; The Hindu 2020b). However, the four states Odisha, Bihar, Uttar Pradesh, and West Bengal have seen the maximum arrival of migrant workers. Odisha has received more than 600,000 internal migrants; a substantial part is from rural areas (Hindustan Times 2020).

Migrants' vulnerability manifested itself in extreme ways in India. When the government announced the lockdown, labor migrants found themselves in a void of economic vulnerabilities as large numbers of migrants lost their income; with no alternatives for their livelihood, migrants returned to their home villages (Haan 2020). Nevertheless, the flow of reverse migration from cities spread the viral infection from the urban "hotspots" to the rural villages. This homecoming became bittersweet for migrants (Sengupta 2020). They were labeled as "carriers of the virus" and stigmatized in their homes and the village, which caused many socio-economic vulnerabilities such as anxiety, unemployment, discrimination, and associated violence (Rajan et al. 2020; Pande 2020; de Haan 2020). Thus, the present study examines the socioeconomic vulnerabilities caused by the COVID-19 pandemic among returnee internal labor migrants in India.

\section{PANDEMICS, MIGRATION, AND VULNERABILITY}

Migration from one area to another in search of improved livelihood is a key feature of human history. While some regions and sectors fall behind in their capacity to 
support populations, others move ahead, and people migrate to access emerging opportunities (Acharya 2020). Migration has become a universal phenomenon in modern times. It has been observed that industrialization and economic development have been accompanied by large-scale movements of people from villages to urban centers (Lusome, Bhagat 2020). However, the recent COVID-19 pandemic has produced a flow of reverse migration from urban to rural. Literature on these topics indicates that, historically, migration during a pandemic period is a phenomenon that negatively impacts the socio-economic conditions of migrants (de Haan 2020).

The study of Rajan, Sivakumar, and Srinivasan (2020) highlighted that the pandemic precipitated a severe "crisis of mobility" and caused the vulnerability of India's internal migrants in terms of their mobility, economic, and health status. Moreover, the pandemic has also affected migrants by various factors, including living and working conditions, service provision, and xenophobia (Liem et al. 2020). Even though the COVID-19 crisis is unprecedented, similar instances have already implemented during different period, for example; Leyva Flores (2018) points out that the $2009 \mathrm{H} 1 \mathrm{~N} 1$ pandemic, which originated in Mexico, prompted other countries to implement isolation (quarantine) mechanisms in populations that had been in Mexico during the period of the epidemic.

Many of these diseases, also called "emerging infectious diseases" because they reach places where they never existed or re-emerge in areas where they had already been eliminated, continue to be linked to migration and mobility population because they can spread throughout the world in a matter of days (Leyva Flores 2018). The impact of these diseases on migration varies from region to region. It similarly happened in 2008 with the cholera outbreak in Zimbabwe, which forced thousands of people to migrate to South Africa. Upon their arrival, many Zimbabwean migrants met discrimination and xenophobia (Edelstein et al. 2014).

A recent study by Guadagno (2020) on migrants and the COVID-19 pandemic pointed out that migrants constitute one of the most vulnerable groups amid the measures taken by the governments to prevent the spread of infectious diseases or in times of epidemics and pandemics. Migrants are stigmatized or blamed for the spreading of the virus. This situation translates into both short and long-term systematic negative socio-economic as well as psychophysical health consequences.

In India, during the pandemic period, millions of migrants returned home. Most of them left with nothing but a keenness to reunite with their families (Rajan, Sivakumar, Srinivasan 2020). People undertook a hazardous journey; they walked hundreds of kilometers with no money to spend and often without food for days together (Ghosh 2020; Jadhav 2020). Law enforcement officials arrested migrants for violating the lockdown; some died due to exhaustion or road accidents. Documents pointed out that upon arrival to the native place, migrants stare at another crisis. Many migrants were stopped at the periphery of their village and were not allowed inside by the fellow villagers for fear of spreading the virus. Some were also forcefully sent to quarantine centers, isolated by family members, friends, and villagers (Ghosh 2020). 
Although the vulnerability faced by migrants has been covered and discussed in media, so far, no systematic study has been conducted in India to understand these phenomena. This paper also aims to contribute to these gaps in the literature on COVID-19 and migration.

\section{METHODOLOGY}

In 2018, the World Bank and the Odisha Higher Education Department jointly established the Centre of Excellence on Regional Development and Tribal Studies. One of the center's main objectives is to analyze the migration and livelihood patterns of the people of western Odisha, India. As a part of this project, we studied the problems, prospects, and perspectives of internal returnee labor migrants due to the COVID-19 pandemic and its impact on their social and migratory status in western Odisha. During June and July 2020, the authors surveyed 227 returned labor migrants in four districts of Odisha' (Sambalpur, Bargarh, Bolangir, Deogarh) (see Map 1) by telephone using close-ended questions. The selected four districts have received 30 percent of the total returned labor migrants in the state of Odisha (Mishra 2020).

The migrants were contacted through the Gram Panchayat ${ }^{2}$ office, as the Government of Odisha instructed all panchayat of the state to collect data regarding migrants' migratory status and contact information. We checked the accuracy of the verbatim interview transcriptions and replaced all personal information with unique pseudonyms to protect participants' identities. In this study, we analyzed the information using SPSS version 22 software, which served to systematize the data on perception and knowledge on COVID-19 and the information on the social and migratory status of migrants. All variables were coded and COVID-19 recoded as frequency and percentages for the descriptive statistics. We also grouped and regrouped codes until the analysis yielded a comprehensive set of themes.

1 The state of Odisha has 30 districts.

2 Gram Panchayat consists of a village or a group of villages divided into smaller units called "Wards". Each ward selects or elects a representative who is known as the Panch or ward member. The members of the Gram Sabha elect the ward members through a direct election. The Sarpanch or the president of the Gram Panchayat is elected by the ward members as per the State Act. The Sarpanch and the Panch are elected for a period of five years. Gram Panchayat is governed by the elected body and administration. The secretary is normally in charge of the administrative duties of the Gram Panchayat. 
Map 1: Enumerated returnee labor migrants in four districts of western Odisha, India

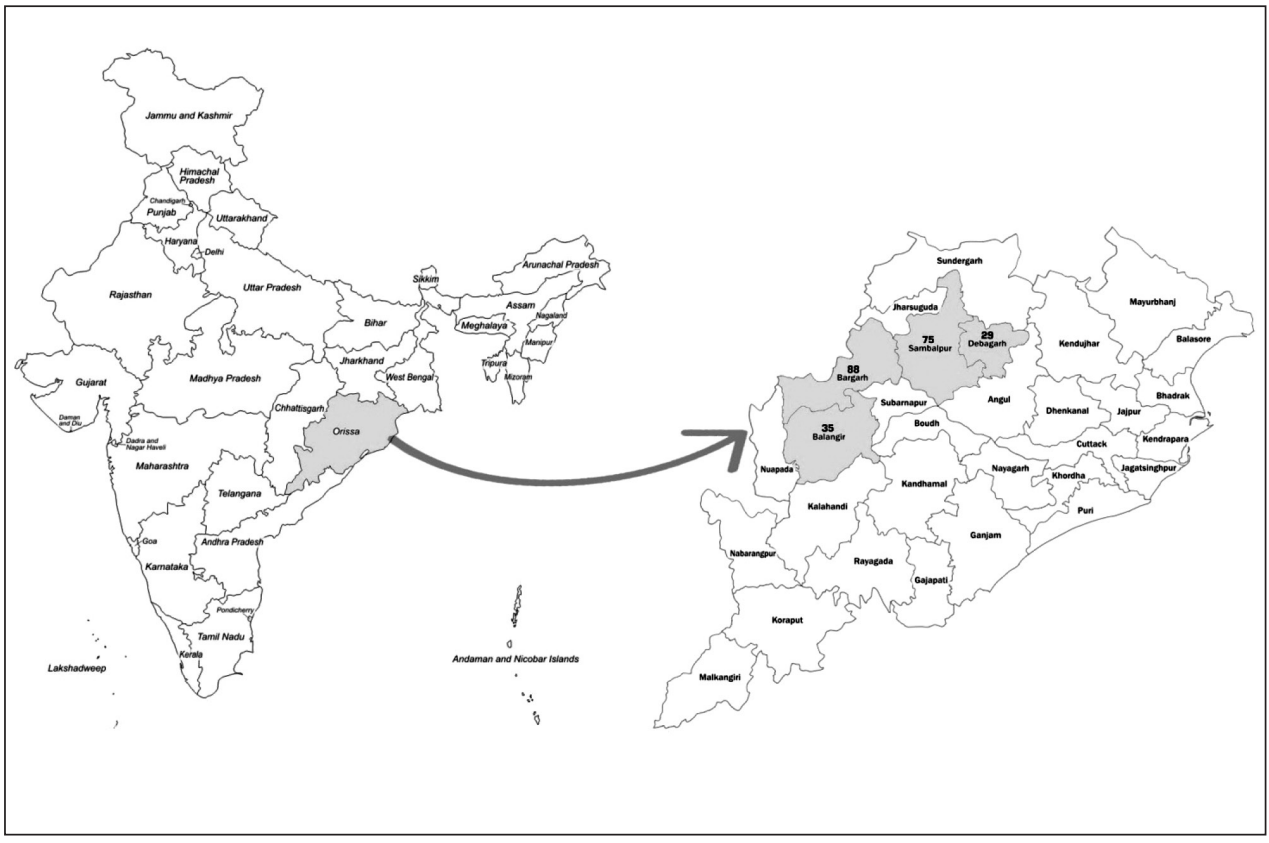

\section{RESULTS}

\section{Socio-demographic Characteristics of Returnee Labor Migrants}

Table 1 presents the socio-demographic characteristics of returnee labor migrants, and as seen, 85 percent $(n=193)$ of migrants are below the age of 35. In terms of educational status, 15 percent of migrants never attended any formal education, nearly fifty percent (46.3 percent, $\mathrm{n}=105$ ) have completed primary school, and 26.9 percent $(n=61)$ have completed secondary level of education. The majority of migrants (48.9 percent, $n=111)$ belong to scheduled caste $(S C)^{3}, 58$ percent $(n=132)$ are unmarried, and more than 87 percent $(n=198)$ identified themselves as very low and low socio-economic groups (see Table 1).

3 The Scheduled Caste (SC) in traditional Indian society is known as Dalit, Harijan, or Untouchable. Traditional Indian society is divided into five main categories of castes: Brahmins, Kshatriyas, Vaishyas, Sudras, and Dalit. Dalits are members of the lowest social group in the Hindu caste system; the word Dalit means "oppressed" or "broken." A Dalit is considered to be born below the caste system, which means below the four primary castes. In 1950, the Constitution of India (including 12 Scheduled Castes) integrated the Dalits into the Schedule of the Constitution for their social, economic, and political development. 
Table 1: Socio-demographic characteristics of returnee labor migrants, India ( $=227$ )

\begin{tabular}{|c|c|c|}
\hline & Number & Percent \\
\hline \multicolumn{3}{|l|}{ Current Age } \\
\hline 17-20 years & 29 & 12.8 \\
\hline $21-25$ years & 79 & 34.8 \\
\hline $26-35$ years & 85 & 37.4 \\
\hline $36-45$ years & 25 & 11.0 \\
\hline More than 45 years & 9 & 4.0 \\
\hline \multicolumn{3}{|l|}{ Education } \\
\hline No education & 34 & 15.0 \\
\hline Primary completed & 105 & 46.3 \\
\hline Secondary completed & 61 & 26.9 \\
\hline College & 27 & 11.9 \\
\hline \multicolumn{3}{|l|}{ Caste } \\
\hline Scheduled caste & 111 & 48.9 \\
\hline Scheduled tribe & 42 & 18.5 \\
\hline Other backward class & 50 & 22.0 \\
\hline Other & 24 & 10.6 \\
\hline \multicolumn{3}{|l|}{ Marital status } \\
\hline Unmarried & 132 & 58.1 \\
\hline Married & 95 & 41.9 \\
\hline \multicolumn{3}{|l|}{ Socio-economic status } \\
\hline Very low & 97 & 42.7 \\
\hline Low & 101 & 44.5 \\
\hline Medium & 29 & 12.8 \\
\hline
\end{tabular}

Source: Fieldwork, 2020.

\section{Occupational Pattern of Returnee Labor Migrants}

As the data indicates (see Table 2), more than half of the total studied migrants (55 percent, $n=126$ ) of four districts migrated to the southern part of India, such as Tamil Nadu $(n=49)$, Andhra Pradesh $(n=33)$, Telangana $(n=23)$, Karnataka $(n=19)$, and Kerala $(n=2)$. Some migrants migrated to northern India, such as Delhi, Uttarakhand. Regarding the occupational pattern, migrant workers gained employment through a sardar (middleman). As the data indicates, about 21 percent $(n=48)$ of returned migrants had worked as agricultural and farm laborers at their place of destination. Further, 19 percent of migrants worked in the textile industry in the 
states of Tamil Nadu, Gujurat, and Tripura, and 11.5 percent worked in the brick kiln industry in the states of Andhra Pradesh, Telangana, and Chhattisgarh. Nearly 12 percent $(n=26)$ worked in hotels and restaurants as service boys or waiters in Delhi, Karnataka, Uttarakhand. Also, 8.4 percent $(n=19)$ worked in the construction sector in the states of Delhi and West Bengal. Some migrants worked as machine operators, others worked in cereal factory, motor parts company, electrical parts shops, poultry farms, or as taxi/auto-rickshaw drivers, among others. Most of these migrants had no contracts and were only employed temporarily.

Table 2: Occupational pattern of returnee labor migrants at the place of destination, India ( $\mathrm{N}=227$ )

\begin{tabular}{|l|r|r|}
\hline & Number & Percent \\
\hline & & \\
Destination state & & \\
Tamil Nadu & 49 & 21.6 \\
Maharashtra & 20 & 8.8 \\
Tripura & 15 & 6.6 \\
Andhra Pradesh & 33 & 14.5 \\
Telangana & 23 & 10.1 \\
Karnataka & 19 & 8.4 \\
West Bengal & 9 & 4.0 \\
Chhattisgarh & 9 & 4.0 \\
Delhi & 14 & 6.2 \\
Uttarakhand & 6 & 2.6 \\
Madhya Pradesh & 11 & 4.8 \\
Gujarat & 17 & 7.5 \\
Kerala & 2 & 0.9 \\
Occupation & & \\
Agriculture and farm labor & & \\
Textile industry & 48 & 21.1 \\
Brick kiln industry & 43 & 19.0 \\
Work in hotel/restaurant & 26 & 11.5 \\
Work in construction sector & 26 & 11.5 \\
Machine operator & 19 & 8.4 \\
Motor parts company & 17 & 7.5 \\
Work in cereal factory & 16 & 7.0 \\
Electrical company & 5.7 \\
Others* & 16.2 \\
& & \\
\hline
\end{tabular}

*Employed in Motor garage, Poultry farm, Colour making industry, Plastic industry, Taxi/auto-rickshaw driver Source: Fieldwork, 2020. 


\section{Migrants Perception on COVID-19}

As in many other populations, migrant workers are more vulnerable to the direct and indirect impacts of COVID-19. Their ability to avoid infection largely depends on the preventive measures they take, including their living and working conditions. We asked a few questions about the migrants' perception of getting infected with COVID-19. As the results indicate, more than half of the total migrants (52 percent, $\mathrm{n}=118$ and 34 percent, $\mathrm{n}=77$ ) perceived very high and high risk, respectively, to get infected of COVID-19 looking into their awareness level, living conditions, and absence of social protection measures (see Figure 1).

Figure 1: Migrants perception to get infected by COVID-19

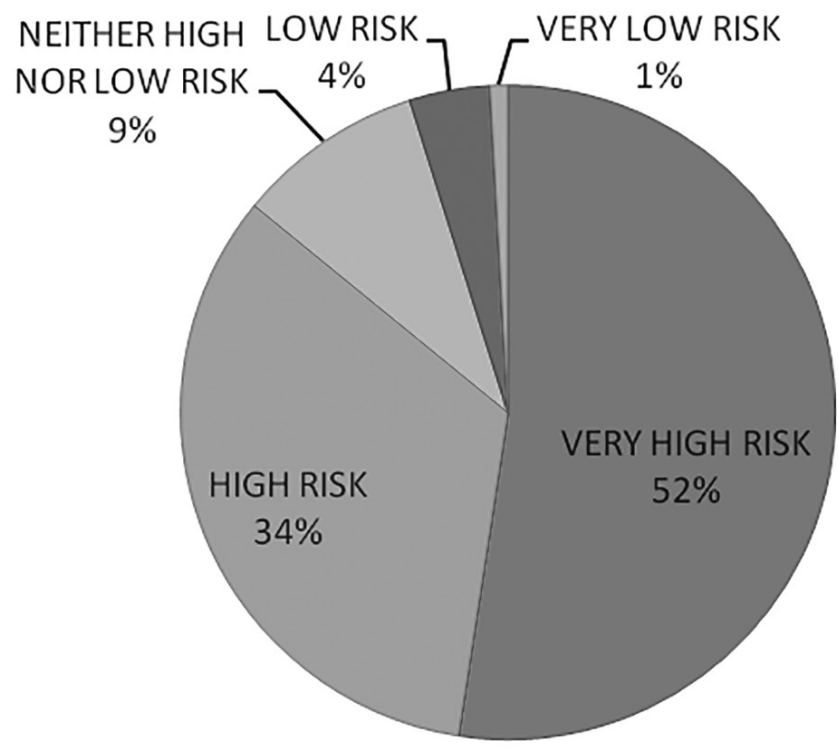

Similarly, on reasons behind returning to the native place, nearly 50 percent $(46.3$ percent, $n=105$ ) left the place of work as industry closed due to COVID-19 lockdown, and 36 percent $(n=82)$ migrants returned as they were deeply worried on the spatial spreading of infection. Many migrants also cited other reasons such as economic complications, fear of getting infected by the Coronavirus, family problems, and no jobs (see Figure 2). Migrants used special train services sponsored by the Government of India to return their homes. Some migrants also rented vehicles and used special bus services sponsored by different non-governmental organizations. 
Figure 2: Reasons behind return to native place

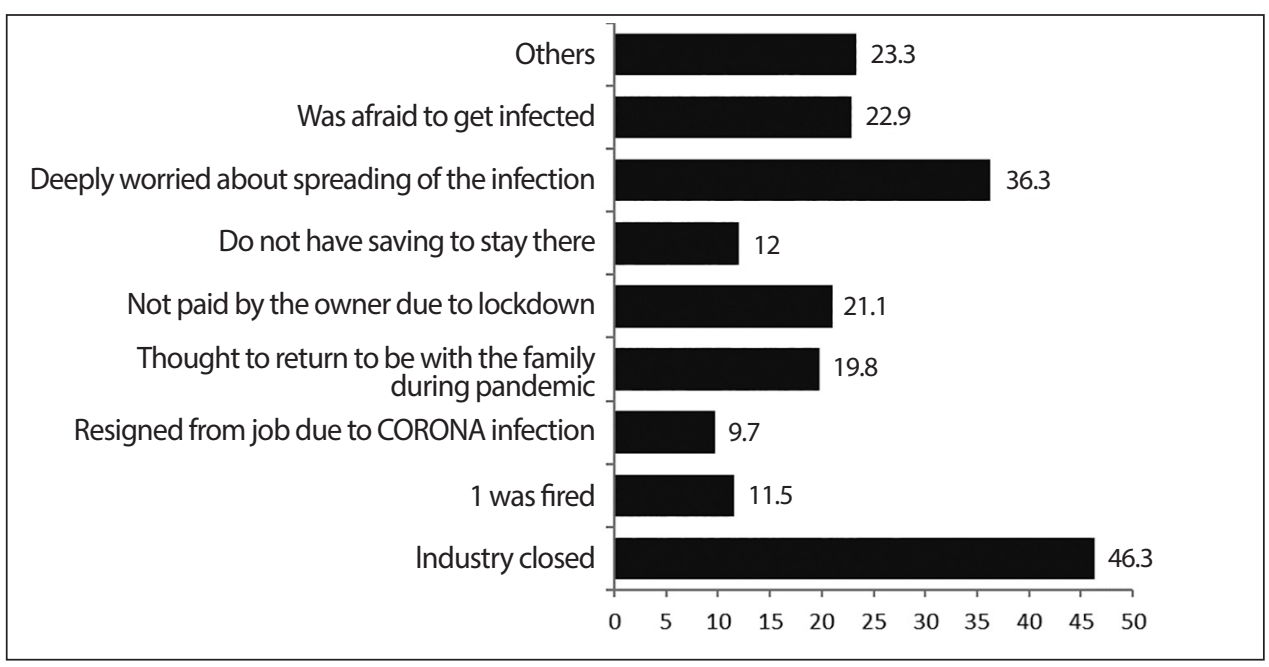

\section{Returnee Labor Migrants and Challenges}

When the Government of Indian announced mandatory lockdown, migrants in cities found themselves in the void of having lost their job and income. Many of them had no alternative and thus returned to their home villages. Upon arrival to native places, migrants faced various social, economic vulnerabilities such as harassment, discrimination, forced quarantine, and abuses. Table 3 categorizes the vulnerability faced by migrants: Social vulnerability, Economic vulnerability, and Abuses and violence. Concerning Social vulnerability, nearly 81 percent $(n=183)$ of returnee labor migrants faced discriminatory attitudes by their native villagers; for example, a migrant said: "When I reached village many people said I am virus carrier and now going to spread virus in the region. They even didn't talk with me. Whenever I come out of home, young people shouted at me, 'Hey Corona.' They also used slang and bad languages against me ..."

Similarly, 86 percent $(n=196)$ of migrants were forcefully sent to quarantine centers by fellow villagers, 71 percent $(n=161)$ suffered evasive behavior, and 59 percent $(n=134)$ were isolated by their own family. However, almost all migrants (98 percent, $\mathrm{n}=223$ ) were not allowed to use common public spaces, including exclusion from social networks (WhatsApp, Facebook, etc.). Although they had come out from the quarantine center, some migrants said their return had caused conflict within their own family members. Moreover, 63 percent $(n=143)$ of migrants were barred from entering their neighbor's house. Another Delhi returned migrant worker quarantined in a house with his family explained how terminology or languages used by fellow villagers could be traumatic. He said: "We were aggressively shouted at and told not to leave the house. The next day two policemen came to the house and threatened us instead of providing necessary information to deal with the quarantine. Their behaviors made us feel like that we are involved in an illicit operation." 
Concerning Economic vulnerability, 73.5 percent $(n=167)$ of migrants said they currently do not possess any job or employment, and a further 88 percent $(n=200)$ responded they had lost their previous job. Migrants also said they were buried in debt (51.5 percent, $n=117$ ) and had lost savings (99 percent, $n=225$ ) (see Table 4). Concerning Abuses and violence faced by returnee labor migrants, 93 percent $(n=$ 211) have faced verbal abuses such as bad language, and 47 percent $(n=107)$ have suffered physical violence by fellow villagers and local authorities, as mentioned by a young migrant:

Upon my return to the village some people complained to village head that probably I have Covid symptoms and may transmit virus in the village, when it came into my knowledge, I explained my health status. However, they didn't convinced and asked me to leave the village. Next day, when I stepped out from house to buy some essentials commodities, while walking I coughed, at that time two men came and accused me that villagers will die because of my fault and suddenly they started beaten me and asked to leave the village immediately.

Table 3: Vulnerabilities faced by returnee labor migrants in their community, India $(\mathrm{N}=227)$

\begin{tabular}{|l|c|c|}
\hline \multicolumn{1}{|c|}{ Vulnerability } & Number & Percent \\
\hline Social vulnerability & & \\
Discrimination & 183 & 80.6 \\
Forced quarantine & 196 & 86.3 \\
Evasive behavior & 161 & 70.9 \\
Family isolation & 134 & 59.0 \\
Not allowed to use common space & 223 & 98.2 \\
Conflict within family & 97 & 42.7 \\
Excluded from social networks (Whatsapp, Facebook, etc.) & 82 & 36.1 \\
Barred from entering neighbor's house after quarantine & 143 & 63.0 \\
& & \\
Economic vulnerability & & \\
Not employed currently & 167 & 73.5 \\
Loss of previous job & 200 & 88.1 \\
Debt & 117 & 51.5 \\
Loss of saving & 225 & 99.1 \\
& & \\
Abuses and violence & 107 & 47.1 \\
Physical & 211 & 92.9 \\
Verbal & & \\
\hline
\end{tabular}

Source: Fieldwork, 2020. 


\section{Behavioral Health Issues of Migrants}

Table 4 describes the behavioral health of returnee labor migrants, where we have classified their responses into two categories: not at all and almost every day. Data shows that the socio-economic vulnerability and abuses (verbal and physical) have deeply impacted migrants' behavioral health, as seen around 52 percent $(n=117)$ of returnee labor migrants said almost every day they consume alcohol. However, when we asked migrants about their self-assessment of psychological behaviors, 83 percent $(n=189)$ reported that almost every day they feel depressed, nearly 88 percent $(n=199)$ feel anxious, and 97 percent $(n=221)$ feel irritated and angry for everything and nearly 91 percent $(n=206)$ migrants have lost appetite due to the current pandemic, economic situations and behaviors encountered upon their arrival. Also, nearly 12 percent $(n=27)$ of migrants almost every day have suicidal ideation as they feel they only exist to overcome the socio-economic damages caused by the pandemic, particularly economic debt, discrimination, prevailing unemployment situation, and other social and economic hardships. In this regards, an adult migrant who returned from the state of Tamil Nadu said:

After the lockdown, the owner of the industry telephoned and said: now it is not possible to pay salary as industry is closed. He also asked us to vacate the house at immediate effect. I was not having sufficient saving, so decided to return to village. Once I reached nearby the village, some people stopped me in mid-way and had a meeting with village committee, and thereafter prohibited me to enter the village territory. They also said I am "virus carrier" and may transmit and infect other people. Many fellow villagers categorized me as "enemy" of all villagers. I tried to convince them about my good health. However, they didn't listen and forcefully sent me to quarantine center, where I stayed nearly 20 days. Now I do not have any job, and I am the only bread earner of my family. Do not know when the pandemic situations get better [...] This caused very tense and anxious [...] Although right now cannot do any things, however, once pandemic over, I may migrate again in search of an opportunity [...]

Similarly, another young migrant who returned from Delhi narrated:

The day when government declared country-wide lockdown, at the very moment, I felt this lockdown definitely caused severe damages in our life. I along with my other friends who were working in a hotel lost our job. We tried to return our village as soon as we can, however, due to non-availability of transport could not make it soon, but after a month with the little saved capital, we returned. On my arrival to village, I encountered with many obstacles. They (family) didn't allowed me to stay in home and sent quarantine center, after that, villagers also excluded in all fronts, which complicated my life to get an employment. Without any job it is hard to maintain life [...] I have taken loans from village head, however, due to absence of earning 
sources at present moment, I am finding difficulty to repay [...] my father is also very sick, and we need money for his treatment. The pandemic has hit us so hard [...] I'm struggling to sit [...] it makes feel very tense, and my head is reeling and do not know what to do ... the situation is so worst that it is better to "quit life" [...]

Table 4: Impacts of vulnerabilities on returnee labor migrants, India $(\mathrm{N}=227)$

\begin{tabular}{|l|c|c|c|c|}
\hline & \multicolumn{2}{|c|}{ Not at all } & \multicolumn{2}{c|}{ Almost every day } \\
\hline \multicolumn{1}{|c|}{ Vulnerability } & Number & Percent & Number & Percent \\
\hline Consumption of alcohol & 110 & 48.5 & 117 & 51.5 \\
Depression & 38 & 16.8 & 189 & 83.2 \\
Feeling anxious and nervous & 28 & 12.4 & 199 & 87.6 \\
Feeling irritated and angry & 6 & 2.7 & 221 & 97.3 \\
Lack of appetite & 21 & 9.3 & 206 & 90.7 \\
Suicidal ideation & 200 & 88.1 & 27 & 11.9 \\
\hline
\end{tabular}

Source: Fieldwork, 2020.

\section{CONCLUSION}

It has been almost a year since the Government of India induced nationwide lockdowns due to COVID-19, and close to 60 million people moved back to their "source" rural areas. The displacement of people has been described as the second-largest since the Partition of India. However, the reality of migrant workers' existence is much more complicated and vulnerable than those sharply defined numbers (Misra 2021). This study provides insight into the socio-economic vulnerability caused by the COVID-19 pandemic among internal returnee labor migrants in India. The lockdown disturbed both the supply chain and demand, causing labor markets to shrink. The sudden paralyzation of economic activities has resulted in deeper shocks and vulnerability among employers and workers. Many migrants who were employed in these sectors have lost their jobs and returned home with limited savings.

For decades, millions of unskilled rural workers have migrated to urban areas, looking for livelihood opportunities. As the current study indicates, migrants are absorbed mainly into the informal economy, such as on construction sites, in the textile industry, in the brick kiln industry, or as a taxi/auto-rickshaw driver in the city. The lockdown forced the migrant population to remain in a vulnerable position as it restricts them from stepping out of their home. The suspension of industrial units, workplaces, and transport caused millions of migrants to deal with the loss of income and an uncertain future. When such employment avenues dwindle, they go back to their rural setting. 
We found that upon their return, migrant workers' social and economic conditions worsen in their native villages. As the studies of Jha (2020) and Dreze (2020) indicate, returnee labor migrants faced fears, discrimination, and unequal treatment in their home communities, leading, on occasion, to confrontations and violence, and this phenomenon affects migrants psychological behaviors. Abuse to migrants with discriminatory labels such as disease carrier, Corona transmitter, social exclusion by the fellow villagers, and the concept of "We versus They" have the power to influence migrants' attitudes and psychological behaviors, for example, by preventing migrants' access to employment and social assimilation. Such abuse also leads to social, psychological isolation, expression of anger, depression, anxiety, constant fear, and loss of appetite, including lifelong hatred, intolerance, alcoholism, and suicidal tendencies among migrants. These negative behaviors in pandemics have been described as co-morbidity where vulnerabilities can exceed the burden of disease.

To mitigate the effect of the lockdown on vulnerable groups, particularly migrants, the Government of India announced different economic packages under the Pradhan Mantri Garib Kalyan Yojana. The package entails an additional five kilograms of wheat or rice and one kg of preferred pulses every month for the next three months. Moreover, the government also ordered the state governments to use the Building and Construction Workers Welfare Fund to provide relief to Construction Workers through direct benefit transfer (DBT) (DHNS 2020; Government of India 2020). The Reserve Bank of India also reduced the interest rate along with a series of unconventional measures to lend to besieged businesses (Bloomberg Quint 2020). Although the relief provided by the government has brought some relief to the migrants, looking into the huge migrant population, the number of services provided still proves highly inadequate. The socio-economic damages and vulnerabilities caused by COVID-19 will definitely continue for an indefinite period. Thus, it is important for governments of all levels (central, state, and district) to address the deep-rooted inequalities that keep workers in marginalized positions, including their essential social protection.

\section{REFERENCES}

Acharya, Arun Kumar (2020). Caste-based Migration and Exposure to Abuse and Exploitation: Dadan Labor Migration in India. Contemporary Social Science, https:// doi.org/10.1080/21582041.2020.1855467.

Bloomberg Quint (2020). Covid-19: Supreme Court Seeks Report From Government On Steps to Prevent Migration of Workers (30 Mar. 2020), https://www.bloombergquint. com/law-and-policy/covid-19-fear-and-panic-bigger-problem-than-coronavirussays-sc-seeks-report-from-govt-on-steps-taken-to-prevent-migration-of-workers (16 Jan. 2021). 
Daftary, Amrita, Frick, Mike, Venkatesan, Nandita, Pai, Madhukar (2017). Fighting TB Stigma: We Need to Apply Lessons Learnt from HIV Activism. BMJ Glob Health, http://dx.doi.org/10.1136/bmjgh-2017-000515.

Daftary, Amrita (2012). HIV and Tuberculosis: The Construction and Management of Double Stigma. Social Science Medicine, https://doi.org/10.1016/j. socscimed.2012.01.027.

Datiko, D. G., Jerene, D., Suarez, P. (2020). Stigma Matters in Ending Tuberculosis: Nationwide Survey of Stigma in Ethiopia. BMC Public Health 20, 190, https://doi. org/10.1186/s12889-019-7915-6.

Deccan Herald News (DHNS) (2020). A Poorly Thought-out Package for the Poor. Deccan Herald, March 27, 2020, https://www.deccanherald.com/opinion/first-edit/apoorly-thought-out-package-for-the-poor-818067.html (5 Apr. 2020).

de Haan, Arjan (2020). Labour Migrants During the Pandemic: A Comparative Perspective. The Indian Journal of Labour Economics 63, 885-900, https://doi. org/10.1007/s41027-020-00283-w.

Dreze, Jean (2020). Averting Hunger During Monsoon Calls for Bold food security measures. The Indian Express, https://indianexpress.com/article/opinion/columns/ nrega-funds-migrant-workers-monsoon-pds-scheme-6449293/ (9 July 2020).

Edelstein, Michael, Heymann, David, Koser (2014). Las crisis sanitarias y la migración. Migraciones Forzadas 45, 36-38, https://www.fmreview.org/es/crisis/edelstein-heymann-koser.

Ghosh, Devarsi (2020). Coronavirus: Migrant Worker who Walked two Days to Get Home Now Faces Stigma, Uncertain Future; https://scroll.in/article/957657/coronavirusmigrant-worker-who-walked-two-days-to-get-home-now-faces-stigma-uncertain-future (5 May 2020).

Government of India (2020). Pradhan Mantri Garib Kalyan Package. Press Information Bureau, March 26, 2020, https://www.mohfw.gov.in/pdf/MoFPMGaribKalyanYojanaPackage.pdf. (5 Apr. 2020).

Government of India (2021). Covid-19 India, Ministry of Health and Family Welfare, https://www.mohfw.gov.in/ (5 Jan. 2021).

Hindustan Times (2020). As Migrant Workers Return, State Govts Gear up to Control Covid-19 Spread, https://www.hindustantimes.com/india-news/as-workers-return-state-govts-gear-up-to-control-spread/story-sof1MtaZSLp3h3EkhNtLEl. html (5 Dec. 2020).

Jadhav, Rajendra (2020). Train Kills Sixteen Workers Laid-off in Coronavirus Lock-down, https://in.reuters.com/article/health-coronavirus-india/train-runs-over-migrantworkers-in-maharashtra-killing-14-idINKBN22KODM (7 Sept. 2020)

Jha, Sujeet (2020). COVID-19: Migrants Kill Resident in Bihar Village for Informing Officials about Their Arrival. India Today (31 Mar. 2020). https://www.indiatoday.in/ india/story/covid-19-migrants-kill-resident-in-bihar-village-for-informing-officials-about-their-arrival-1661626-2020-03-31 (7 Sept. 2020). 
Kakar, Vedika (2020). Differently-abled Migrant Women Workers Grapple with the Pandemic. The Leaflet, https://theleaflet.in/differently-abled-migrant-women-workers-grapple-with-the-pandemic/ (26 Jan. 2021).

Leyva Flores, Rene (2018). Conceptos sobre migración y salud: Entre las cuarentenas y los determinantes de la salud. Cuadernos Médicos Sociales 58/4, 33-39, https:// www.saludymigracion.org/es/system/files/repositorio/7_conceptos_migracion_cuad_med_18.pdf.

Liem, Andrian, Wang, Cheng, Wariyanti, Yosa, Latkin, Carl, Hall, Brian (2020). The Neglected Health of International Migrant Workers in the COVID-19 Epidemic. The Lancet 7/4, https://www.thelancet.com/journals/lanpsy/article/PIIS22150366(20)30076-6/fulltext (26 Jan. 2021).

Lusome, Raman., Bhagat, Ram Babu (2020). Migration in Northeast India: Inflows, Outflows and Reverse Flows during Pandemic. The Indian Journal of Labour Economics 63/4, 13, 1125-1141, https://doi.org/10.1007/s41027-020-00278-7.

Mishra, Ashutosh (2020). Odisha Government III-Prepared to Handle the Lakhs of Migrant Workers Coming Home, The Wire (4 May 2020). https://thewire.in/government/odisha-migrant-workers-quarantine-jobs (17 Feb. 2021).

Misra, Udit (2021). Explain Speaking: What 2020 Taught us About India's Internal Migration, The Indian Express, https://indianexpress.com/article/explained/what-2020-taught-us-about-indias-internal-migration-explainspeaking-7189053/ (18 Feb. 2021).

Pande, Amba (2020). COVID-19 and the Distress Reverse Migration in India: A Gendered Perspective. Global Research Forum on Diaspora and Transnationalism (GRF$D T$ ), https://grfdt.com/PublicationDetails.aspx?Type=Articles\&Tabld=10144.

Pandey, Vikas (2020). Coronavirus Lockdown: The Indian Migrants Dying to Get Home. BBC News, https://www.bbc.com/news/world-asia-india-52672764 (18 Feb. 2021).

Rajan, S. Irudaya, Sivakumar, P., Srinivasan, A. (2020). The COVID-19 Pandemic and Internal Labour Migration in India: A 'Crisis of Mobility' The Indian Journal of Labour Economics, https://doi.org/10.1007/s41027-020-00293-8.

Sengupta, Rajit (2020). COVID-19: Cities Become Hotspots Again. Down to Earth, Monday, November 30, https://www.downtoearth.org.in/news/health/covid-19-cities-become-hotspots-again-74448 (20 Jan. 2021).

The Hindu (2020a). Helpline providing COVID-19 Mental Health Counselling in 21 States: NIMHANS tells HC. The Hindu, https://www.thehindu.com/news/national/karnataka/helpline-providing-covid-19-mental-health-counselling-in-21-states-nimhans-tells-hc/article31466837.ece (20 Jan. 2021).

The Hindu (2020b). Outdated Census Data Deprives over 10 Crore of PDS: Economists. The Hindu, https://www.thehindu.com/news/national/outdated-census-datadeprives-over-10-crore-of-pds-economists/article31350648.ece (20 Jan. 2021).

World Health Organization (WHO) (2021). Weekly Epidemiological Update - April 4, 2021, https://www.who.int/publications/m/item/weekly-epidemiologicalupdate-on-covid-19---6-april-2021 (8 Apr. 2021). 


\section{POVZETEK}

\section{RANLJIVOST NOTRANJIH MIGRANTOV POVRATNIKOV MED PANDEMIJO COVIDA-19 V INDIJI Arun Kumar ACHARYA, Sanjib PATEL}

Popolni lockdown zaradi pandemije Covida-19 marca in aprila 2020 in delni lockdowni v številnih zveznih državah so v Indiji povzročili eksodus delovnih migrantov. Zaradi zapiranja tovarn in delovnih mest so se milijoni migrantskih delavcev soočili z izgubo dohodka in dela, s pomanjkanjem hrane in z negotovo prihodnostjo. Brez alternativnih možnosti za preživetje so se množično vračali v domače vasi. Obratni tok migracij iz mest na deželo je prispeval k širitvi koronavirusa iz tako imenovanih urbanih hotspotov na podeželje. Vrnitev domov je bila za migrante grenko-sladka izkušnja, v njihovih vaseh so jih stigmatizirali kot »prenašalce virusa« in jih diskriminirali, kar je pri njih povzročalo anksioznost in druge oblike družbenoekonomske ranljivosti. Iz tega razloga pričujoči članek analizira vse oblike ranljivosti, ki jih je pandemija Covida-19 povzročila med notranjimi migranti povratniki v Indiji. Študija, junija in julija 2020 izvedena v telefonski anketi z zaprtimi vprašanji, je zajela 227 delovnih migrantov povratnikov iz štirih okrajev zahodne Orise.

Rezultati kažejo, da sta delni in popolni lockdown po celi državi zaprla tovarne in delovna mesta. Milijoni migrantov so se zaradi izgube dohodka soočali z negotovo prihodnostjo, kar jih je prisililo k vračanju v njihovo »izvorno « kmečko okolje. Ta množična selitev ljudstva je druga največja v zgodovini države vse od razdelitve Indije, vendar pa so resnične delavske usode precej bolj zapletene in ranljive od navedenih številk. Študija omogoča vpogled v vse oblike družbenoekonomske ranljivosti, ki jo je pandemija Covida-19 povzročila med notranjimi migranti povratniki v Indiji. Lockdown je zmanjšal ponudbo in povpraševanje ter skrčil trg dela. V omenjenih sektorjih zaposleni migranti so izgubili delo in se s skromnimi prihranki vrnili domov, kjer so bili deležni tako družbene kot ekonomske diskriminacije, izključenost, ki so je bili deležni s strani sorodstva in sovaščanov, pa je še dodatno vplivala na njihovo duševno zdravje. 